Heparanase activity is correlated with the metastatic potential of several cancer cells and is a key enzyme in the breakdown of tissue barriers. It is also involved in the regulation of growth factor and cytokine activity. However, little is known about the factors that induce heparanase in cancer cells. We investigated the effect of three growth factors, plateletderived growth factor (PDGF), hepatocyte growth factor (HGF) and basic fibroblast growth factor (bFGF), on heparanase mRNA induction in lung cancer cells in vitro. In addition, we examined the effect of erythromycin (EM) and clarithromycin (CAM), which are 14-membered ring macrolide antibiotics that act as biological response modifiers, on the expression of heparanase mRNA induced by growth factors.

PDGF, HGF and bFGF stimulated cell migration activity and enhanced the expression of heparanase mRNA in the human lung adenocarcinoma cell line A549. Via different mechanisms, EM and CAM modulate the induction by these factors of heparanase mRNA expression on A549 cells. EM also significantly suppressed A549 cell migration induced by PDGF and HGF, and CAM significantly suppressed A549 cell migration induced by bFGF.

The results suggest that the growth factors PDGF, HGF and bFGF are important inducers of heparanase in potentially invasive and metastatic cancer cells. The suppressive effect of heparanase mRNA expression by EM and CAM may have interesting therapeutic applications in the prevention of metastasis.

Key words: Heparanase, Lung cancer, Growth factor, Erythromycin, Clarithromycin

\section{Erythromycin and clarithromycin modulation of growth factor-induced expression of heparanase mRNA on human lung cancer cells in vitro}

\author{
Masahiro Sasaki ${ }^{\mathrm{CA}}$, Takefumi Ito, \\ Masayuki Kashima, Shin Fukui, Noriko Izumiyama, \\ Akiko Watanabe, Masaaki Sano, Yosimasa Fujiwara \\ and Mamoru Miura
}

Second Department of Internal Medicine, Akita University School of Medicine, 1-1-1 Hondo, Akita 010, Japan

\author{
${ }^{\mathrm{CA}}$ Corresponding Author \\ Tel: +81 188846107 \\ Fax: +81 188362612 \\ E-mail: masahiro@im2.med.akita-u.ac.jp
}

\section{Introduction}

Cancer cell migration through the basement membranes and degradation of extracellular matrix proteins play an essential role in the various biological and pathological processes in tumor invasion and metastasis.

Histological specimens from lung cancers have documented that central fibrosis and active fibroblast proliferation are among the most important prognostic factors for small bronchioalveolar carcinoma. ${ }^{1,2}$ These same studies emphasized the importance of cancer cell-fibroblast interactions in the process of metastasis. These interactions regulate growth factor and matrix metalloproteinase (MMP) production in cancer cells, which leads to the continuation of cell migration. ${ }^{3-5}$

Heparan sulfate proteoglycans (HSPGs) are primarily the chief component of extracellular matrix protein and are also important structures in basement membranes. HSPGs are thought to be involved in cell adhesion, migration, proliferation and angio- genesis. ${ }^{6,7}$ Various classes of enzymes have been reported to play a role in the metastatic process including serine and cysteine protease, MMP and heparanase. ${ }^{8-11}$

Heparanase is an endo- $\beta$-D-glucuronidase capable of heparan sulfate cleavage, and is reportedly found mainly in platelets, placental trophoblasts, leukocytes, melanomas and hepatomas. ${ }^{12-15}$ Recently, overexpression of heparanase in tumor cells was shown to confer a high metastatic potential in experimental mice. ${ }^{16,17}$ These reports suggested that heparanase may be the key enzyme in the breakdown of tissue barriers and may be involved in the regulation of growth factors and cytokine activity. However, less is known about the factors that induce heparanase mRNA expression on cancer cells during invasion and metastasis.

Erythromycin (EM) and clarithromycin (CAM) are 14-membered ring macrolide antibiotics that reportedly suppress neutrophil accumulation and effectively treat chronic lower respiratory tract disease. ${ }^{18}$ Recent studies have suggested that compounds of this class 
limit tumor growth factors. ${ }^{19}$ Furthermore, roxithromycin, another 14-membered ring macrolide antibiotic, has been shown to have an inhibitory effect on tumor angiogenesis. ${ }^{19}$ These findings suggest that EM and CAM may have anti-metastatic effects on the host-defense system. ${ }^{20.21}$

Consequently, we investigated the effects of growth factors on the induction of heparanase mRNA expression on lung cancer cells in vitro. Additionally, we examined the effect of EM and CAM on the expression of heparanase mRNA induced by growth factors in vitro.

\section{Materials and methods}

\section{Materials}

Recombinant human platelet-derived growth factor (PDGF)-BB, hepatocyte growth factor (HGF) and basic fibroblast growth factor (bFGF) were purchased from Genzyme (USA). Heparin (porcine), for which activity was $1 \times 10^{3} \mathrm{U} / \mathrm{ml}$, was purchased from Novo Nordlisk (Denmark). EM was provided by Dainavot Pharmaceutical Co., Ltd (Japan), and CAM was provided by Dainihon Pharmaceutical Co., Ltd (Japan). Tissue culture plates were obtained from Sumitomo Bakelite (Japan) and Transwell culture dishes were from Corning Coster (USA). The Matrigel invasion chamber was supplied by Falcon (USA).

\section{Cell culture}

Human lung fibroblasts-1, obtained from Riken Cell Bank (Japan), were cultured in a cell culture flask in modified Ham's F12 (Sigma) supplemented with 10\% fetal calf serum (FCS) at $37^{\circ} \mathrm{C}$ in an atmosphere of $5 \%$ $\mathrm{CO}_{2}$ without antibiotics. A549 cells (human lung adenocarcinoma), obtained from Japanese Cancer Research Resources Bank (Japan), were cultured in a cell culture flask in RPMI1640 (Sigma) supplemented with $10 \% \mathrm{FCS}$ at $37^{\circ} \mathrm{C}$ in an atmosphere of $5 \% \mathrm{CO}_{2}$, 95\% air without antibiotics. The cells grown to confluence were removed from the culture flask, plated at $1.0 \times 10^{5}$ cells in a $35 \mathrm{~mm}$ petri dish and incubated with PDGF $(2 \mu \mathrm{g} / \mathrm{ml})$, HGF $(4 \mu \mathrm{g} / \mathrm{ml}), \mathrm{bFGF}$ $(2 \mu \mathrm{g} / \mathrm{ml})$ and heparin $(10 \mathrm{U} / \mathrm{ml})$ without serum and antibiotics for $6 \mathrm{~h}$. Cells were removed from the plates with phosphate-buffered saline and ethylenediaminetetraacetic acid, replaced and suspended in a micro test tube with $1 \mathrm{ml}$ of F12 or RPMI 1640 media. Cell counts and viability were determined by Trypan blue exclusion (GIBCO) and counted by a hemocytometer. To investigate the effect of EM and CAM, we cultured A549 cells and fibroblasts with EM $(10 \mu \mathrm{g} / \mathrm{ml})$ and CAM $(10 \mu \mathrm{g} / \mathrm{ml})$ for $30 \mathrm{~min}$ prior to the addition of the growth factors.

\section{Cell migration assay}

Cell migration induced by PDGF $(2 \mathrm{ng} / \mathrm{ml})$, HGF $(4 \mathrm{ng} / \mathrm{ml})$, bFGF $(2 \mathrm{ng} / \mathrm{ml})$ and heparin $(10 \mathrm{U} / \mathrm{ml})$ were measured using the modified Boyden chamber as described previously. ${ }^{14}$ The test compounds diluted with Ham's F12 medium were placed in wells in the upper chamber. The wells were covered with Matrigel-coated polycarbonate filters. Human lung fibroblasts $\left(5 \times 10^{4}\right.$ cells) and medium were then added to the wells in the upper chamber. Using the same method as already described, A549 cells $\left(5 \times 10^{4}\right.$ cells $)$ and medium were then added to the wells in the upper chamber. PDGF, HGF and bFGF were added to the wells in the upper chamber for the migration assay. Heparin $(10 \mathrm{U} / \mathrm{ml})$ was used as the antiheparanase compound. After a $6 \mathrm{~h}$ incubation at $37^{\circ} \mathrm{C}$ in $5 \% \mathrm{CO}_{2}$, the filters were removed and cells were fixed and stained using Diff-Quik stain (International Reagents Co., Japan). Cell migration was determined by counting the number of cells/microscopic field on the lower surface.

\section{Reverse transcription polymerase chain reaction amplification}

Total RNA was extracted from fibroblasts and A549 cells using the acid-guanidinium-phenol method, as per the manufacturer's instructions (AmpliTaq Gold; Roch Molecular System, Inc., USA). First-strand cDNA was prepared from $0.3 \mu \mathrm{g}$ of total RNA in a $20 \mu 1$ reaction volume that consisted of $50 \mathrm{mM}$ of Tris $(\mathrm{pH}$ $8.3), 75 \mathrm{mM}$ of $\mathrm{KCl}, 3 \mathrm{mM}$ of $\mathrm{MgCl}_{2}, 10 \mathrm{mM}$ of dithiothreitol, $0.5 \mathrm{mM}$ of dNTPs, $120 \mathrm{U}$ of RNAse inhibitor, and $16 \mathrm{U}$ of reverse transcriptase (RT).

Oligonucleotide primers for polymerase chain reaction (PCR) amplification of heparanase were designed according to published DNA sequences for heparanase. ${ }^{17}$ The following primers were used:

\section{HPU-380Y, 5'-CGATCCCAAGAAGGAATCAA-3' ;}

\section{HPL-812Y, 5' -TAACTGCGACCCATTGATGA-3' .}

Amplification was performed in a final volume of $100 \mu 1$ with $15 \mathrm{mM}$ of Tris ( $\mathrm{pH} 8.0$ ), $50 \mathrm{mM}$ of $\mathrm{KCl}$, $1.5 \mathrm{mM}$ of $\mathrm{MgCl}_{2}, 0.2 \mathrm{mM}$ of dNTPs, $1.0 \mu \mathrm{mol}$ of each primer and $2.5 \mathrm{U}$ of Taq polymerase. After a "hot-start" $\left(95^{\circ} \mathrm{C}, 10 \mathrm{~min}\right)$, each cycle consisted of $40 \mathrm{sec}$ of denaturation at $94^{\circ} \mathrm{C}, 1 \mathrm{~min}$ of annealing at $58^{\circ} \mathrm{C}$, and 2 min of elongation at $72^{\circ} \mathrm{C}$. Reactions were run for 35 cycles.

\section{Data analysis}

Results are expressed as mean \pm the standard error of the mean (SEM). A comparison of the effect of A549 cell migration within experiments was performed by analysis of variance. Statistical significance was established at the $p<0.05$ level. 

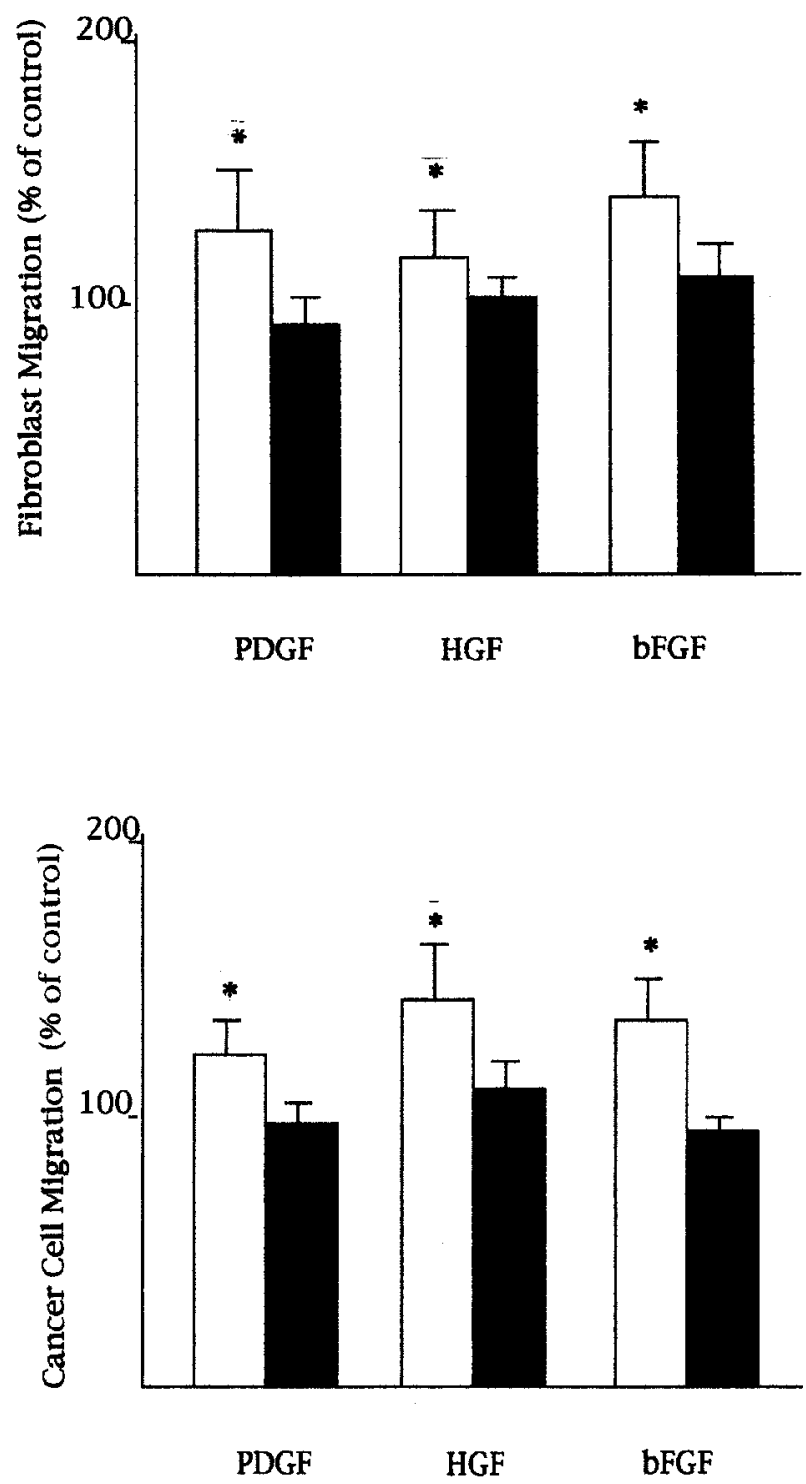

FIG. 1. Cell migration assay in response to PDGF, HGF and bFGF. Bar graph representing the effect of stimulus alone ( $\square$ ) and stimulus in the presence of heparin ( $\square$ ). PDGF, HGF and bFGF induced significantly increased migration in both fibroblasts and lung cancer cells (A549). Heparin inhibited both fibroblast and lung cancer cell migration induced by PDGF, HGF and bFGF. The vertical line represents the SEM of quadruplicate analyses. ${ }^{*} p<0.05$ when compared with controls (no factors).

\section{Results}

\section{Cell migration assay}

PDGF, HGF and bFGF induced significantly increased migration in human lung fibroblasts and A549 cells, whereas heparin significantly inhibited cell migration in both $(p<0.05$; Fig. 1). EM and CAM did not suppress fibroblast migration induced by PDGF, HGF and bFGF (data not shown).

However, EM significantly suppressed A549 cell migration induced by PDGF and HGF, and CAM significantly suppressed A549 cell migration induced by bFGF $(p<0.05$; Fig. 2$)$.

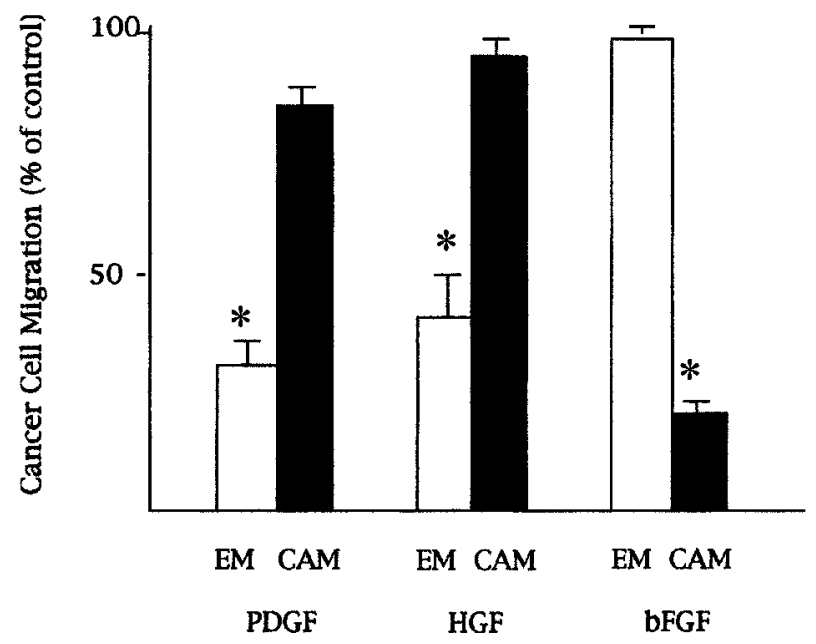

FIG. 2. Bar graph representing the effect of EM and CAM on A549 cell migration induced by PDGF, HGF and bFGF. The vertical line represents the SEM of quadruplicate analyses. * $p<0.05$ when compared with individual growth factor treatment only.

\section{Effect of growth factors on heparanase mRNA} expression in human lung fibroblast

Fibroblasts when cultured with serum-free medium revealed weakly expressed heparanase mRNA, which was not increased by PDGF, HGF or bFGF. Heparin had no inhibitory effects on heparanase mRNA expression (Fig. 3).

Effect of growth factors on heparanase mRNA expression in A549 cells

A549 cells did not express heparanase mRNA when cultured with serum-free medium. However, growth factors such as PDGF, HGF and bFGF did induce heparanase mRNA expression. Heparin had no inhibitory effects on heparanase mRNA expression (Fig. 3).

\section{Effect of EM and CAM on heparanase mRNA induced by growth factors in A549 cells}

EM suppressed the expression of heparanase mRNA induced by PDGF and HGF, but did not suppress heparanase mRNA expression induced by bFGF (Figs. 4 and 5).

In contrast, CAM suppressed expression of heparanase mRNA induced by bFGF, but not that induced by PDGF or HGF (Fig. 6).

\section{Discussion}

In the present study, we demonstrated that PDGF, HGF and bFGF stimulated cell migration of the human lung cancer cell line. More importantly, these growth factors induced heparanase mRNA expression on the lung cancer cell line in vitro. 


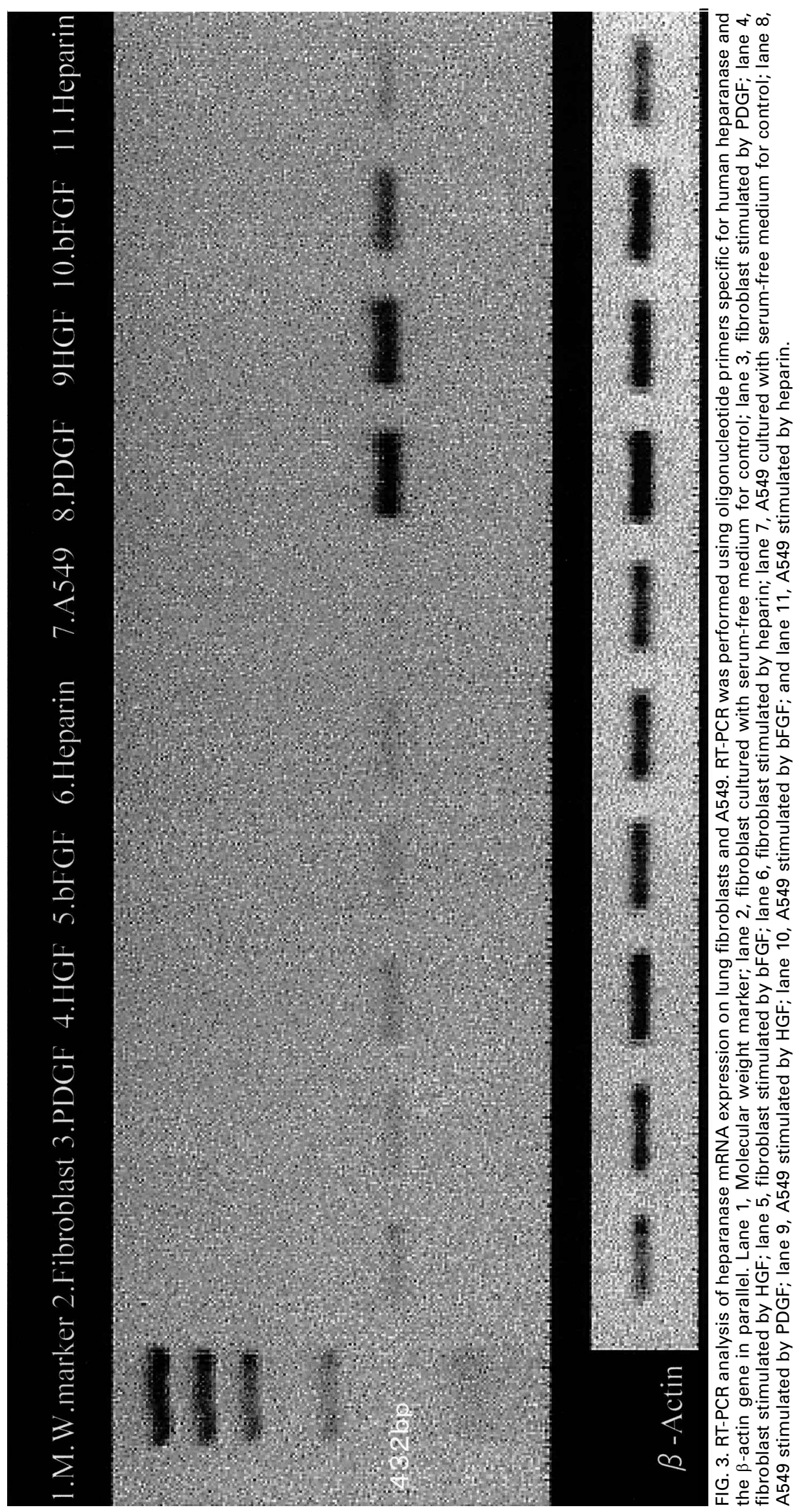




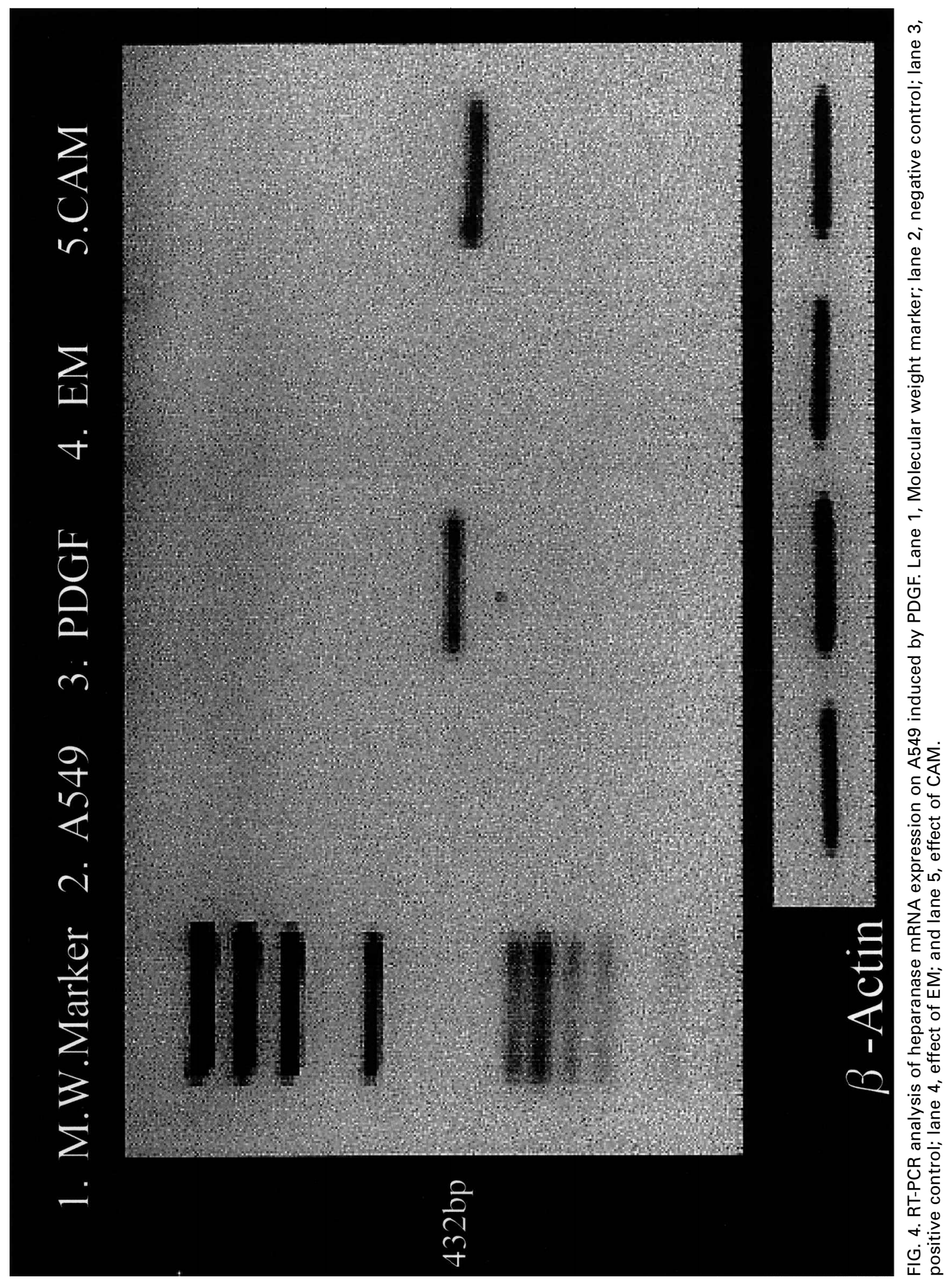




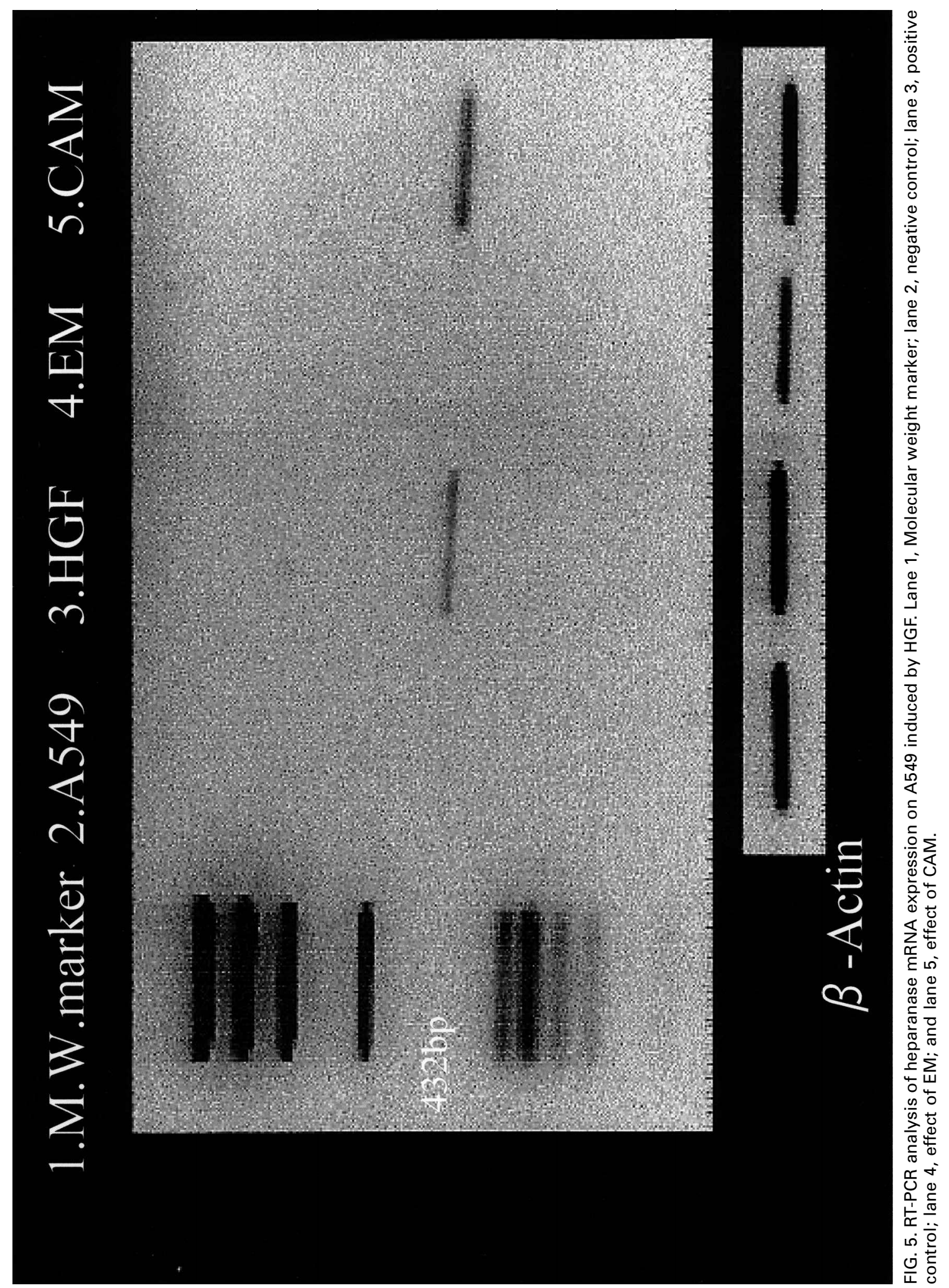




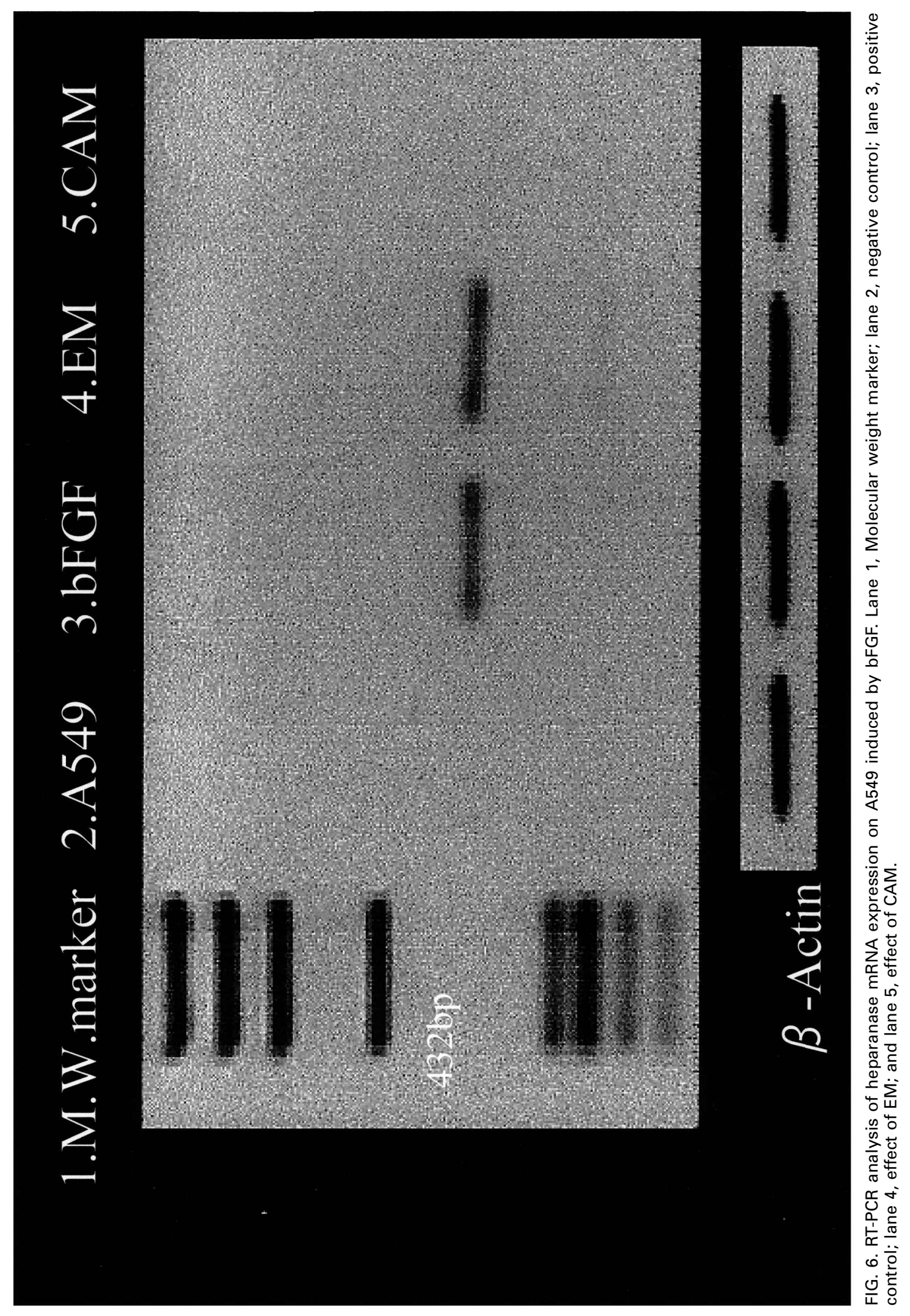


Tumor cell migration plays an important role in the process of metastasis. $^{22}$ Growth factors, including PDGF, HGF and bFGF, and extracellular matrix components are known requirements for cell migration. ${ }^{23}$ Furthermore, the existence of PDGF and PDGF receptors is reported to be a prognostic indicator in lung cancers. ${ }^{24}$ Produced by several tumor cells, fibroblasts and endothelial cells, bFGF has been implicated in the induction of the angiogenic and stromal responses. ${ }^{25}$ Also, it is now recognized that HGF has multiple effects, such as mitogenic, motogenic, and angiogenic effects. ${ }^{26}$ These growth factors are produced by tumor and tumor-associated host tissue such as fibroblasts and mesenchymal cells. ${ }^{27,28}$ To determine whether growth factors play a biological role in the migration of human lung fibroblasts and cancer cells, we used a cell migration assay employing the modified Boyden chamber method. The cells migrated in a dose-dependent manner (data not shown), suggesting that PDGF, HGF and bFGF influence A549 cells and fibroblast migration. Additionally, PDGF, HGF and bFGF induced heparanase mRNA expression on A549 cells but not on fibroblasts. Our previous study demonstrated that MMP-1 and MMP-9 were strongly positive in the cytoplasma of fibroblasts, and they retained MMP-1 and MMP2/MMP-9 activity when stimulated by PDGF. ${ }^{6}$ More recent studies have demonstrated that heparin and MMP-2 correlate with the proteolytic cleavage sites of fibronectin and anti-adhesive effects. ${ }^{29}$ These results suggest that fibroblasts and tumor cells may employ different mechanisms of cell migration. Our data supports the fact that heparanase is inducible in A549 cells by growth factors that also increase migration of these cells in vitro.

Our results provide proof that growth factors do indeed play an important role in the induction of heparanase mRNA expression in potentially invasive and metastatic cancer cells. Inhibition of these growth factors, which usually cause increased expression of heparanase, may have a net effect of inhibiting tumor metastasis.

Our data revealed that heparin inhibited growth factor-induced A549 cell migration, which is supported by the fact that heparin is one of the heparanase-inhibitory molecules. ${ }^{30-33}$

Our cell migration assay demonstrated that EM inhibited A549 cell migration induced by PDGF and HGF, whereas CAM inhibited A549 cell migration induced by bFGF. We also found that EM and CAM modulated heparanase mRNA expression on A549 cells induced by growth factors, but in a differential manner. Recent studies have shown that EM enhances natural killer cell activity and increases the survival times of tumor-bearing mice. ${ }^{34}$ It has also been found that CAM increases natural killer cell activity and CD8 T-cell cytotoxicity to reduce tumor growth in the murine lung cancer model. ${ }^{35}$ We report here for the first time that EM and CAM suppress heparanase mRNA expression and thus inhibit tumor cell migration. However, further study is required to understand the different mechanisms that occur for EM suppression of PDGF-induced and HGF-induced heparanase mRNA expression, and for the CAM suppression of bFGF-induced expression of heparanase mRNA.

In conclusion, our results provide clear evidence that PDGF, HGF and bFGF growth factors are important inducers of heparanase in potentially invasive and metastatic cancer cells. EM and CAM produce inhibitory effects on growth factors that induce heparanase mRNA expression and may, therefore, have possible therapeutic applications in the future.

ACKNOWLEDGEMENTS. The authors thank Dainabot Co., Ltd (Japan) and Dainihon Pharmaceutical Co., Ltd (Japan) for the kind donation of erythromycin and clarithromycin.

\section{References}

1. Pard A, Selman M, Ramirez R, Ramos C, Montano M, Stricklin G, Raghu G Production of collagenase and tissue inhibitor of metalloproteinases by fibroblasts derived from normal and fibrotic human lungs. Chest 1992; 102: $1085-1089$

2. Noguchi M, Morikawa A, Kawasaki M, Masuno Y, Yamada T, Hirohashi S, Kondo H, Shimosato Y. Small adenocarcinoma of the lung. Histological characteristics and prognosis. Cancer 1995; 75: 2844-2852.

3. Biswas C. Tumor cell stimulation of collagenase production by fibroblast. Biochem Biophys Res Commun 1982; 109: 1026-1034.

4. Chin JR, Murphy G, Werb Z. Stromelysin, a connective tissue-degrading metaloendopeptidase secreted by stimulated rabbit synobial fibroblasts in parallel with collagenase. J Biol Chem 1985; 260: 12367-12736.

5. Duffy MJ. The role of proteolytic enzymes in cancer invasion and metastasis. Clin Exp Metast 1992; 10: 145-155.

6. Sasaki M, Kashima M, Ito T, Watanabe A, Sano M, Kagaya M, Shioya T, Miura M. Effect of heparin and related glycosaminoglycan on PDGFinduced lung fibroblast proliferation, chemotactic response and matrix metalloproteinases activity. Mediators Inflammation 2000; 9: 85-91.

7. Lapierre F, Holme K, Lam L, Tressler RJ, Storm N, Wee J, Stack RJ, Castellot $\mathrm{J}$, Tyrrell D. Chemical modification of heparin that diminish its anticoagulant but preserve its heparanase-inhibitory, angiostatic, antitumor and anti-metastatic properties. Glycobiology 1996; 6: 355-366.

8. Nakajima M, Irimura $\mathrm{T}$, Di Ferrante $\mathrm{N}$, Nicholson GL. Metasatatic melanoma cell heparanase. Characterization of heparan sulphate degradation fragments produced by B16 melanoma endoglucuronidase. J Biol Chem 1984; 259: 2283-2290.

9. Nakajima M, Irimura T, Nicolson G. Heparanase and tumor metastasis. $J$ Cell Biochem 1988; 36: 157-167.

10. Gray ST, Yun K, Motoori T, Kuys YM. Interstitial collagenase gene expression in colon neoplasia. Am J Pathol 1993; 143: 663-671.

11. Vaday GG, Lider O. Extracellular matrix miotics, cytokines, and enzymes dynamic effects on immune cell behavior and inflammation. J Leukoc Biol 2000; 67: 149-159.

12. Vlodavsky I, Eldor A, Haimovitz-Friedman A, Matzner Y, Ishai-Michaeli R, Lider O, Naparstek Y, Cohen IR, Fuks Z. Expression of heparanase by platelet and circulating cells of the immune system: possible involvement in diapedesis and extravasation. Invasion Metastasis 1992; 12 112-127.

13. Freeman C, Parish CR. Human platelet heparanase: purification, charac terization and catalytic activity. Biochem J 1998; 330: 1341-1350.

14. Vlodavsky I, Fuks Z, Bar-Ner M, Ariav Y, Schirrmacher V. Lymphoma cell mediated degradation of sulphate proteoglycans in the subendotherial extracellular matrix: relationship to tumor cell metastasis. Cancer Res 1983; 43: 2704-2711.

15. Gilt D, Hershkoviz R, Goldkorn I, Cahalon L, Korner G, Vlodavsky I, Lider O. Molecular behavior adapts to context: heparanase function as an extracellular matrix-degrading enzyme or as a T cell adhesion molecule, depending on the local pH. J Exp Med 1995; 181: 1929-1934.

16. Vlodavsky I, Friedmann Y, Elkin M, Aingorn H, Atzmon R, Ishai-Michheli R, Bitan M, Pappo O, Peretz T, Michal I, Spector L, Pecker I. Mammalian heparanase: gene cloning, expression and function in tumor progression and metastasis. Nat Med 1999; 5: 793-802.

17. Hulett MD, Freeman C, Hamdorf BJ, Baker RT, Harris MJ, Parish CR Cloning of mammalian heparanase, an important enzyme in tumor invasion and metastasis. Nat Med 1999; 5: 803-809. 
18. Kadota J, Sakito O, Kohono S, Sawa H, Mukae H, Oda H, Kawakami K, Fukusima K, Hirayani K, Hara K. A mechanism of erythromycin treatment in patients with diffuse panbronchiolitis. Am Rev Respir Dis 1993; 147: 153-159.

19. Yatsunami J, Tsuruta N, Fukuno Y, Kawashima M, Taniguchi S, Hayashi S. Inhibitory effects of roxithromycin on tumor angiogenesis, growth and metastasis of mouse B16 melanoma cell. Clin Exp Metastasis 1999; 17: 119-124.

20. Hamada K, Kita E, Sawaki M, Mikasa K, Narita N. Antitumor effect of erythromycin in mice. Chemotherapy 1995; 41; 59-69.

21. Mikasa K, Sawaki M, Kita E, Hamada K, Teramoto S, Sakamoto M, Maeda K, Konishi M, Natita N. Significant survival benefit to patients with advanced non-small-cell lung cancer from treatment with Clarithromycin. Chemotherapy 1997; 43: 288-296.

22. Erkell LJ, Schirrmacher V. Quantitative in vitro assay for tumor cell invasion through extracellular matrix or into protein gels. Cancer Res 1988; 48: 6933-6937.

23. Bredin CG, Liu Z, Hauzenberger D, Klominek J. Growth-factor-dependent migration oh human lung-cancer cells. Int J Cancer 1999; 82: 338-345.

24. Kawai T, Hiroi S, Totikata C. Expression in lung carcinomas of plateletderived growth factor and its receptors. Lab Invest 1997; 77: 431-436.

25. Siegfried JM, Weissfeld LA, Luketich JD, Weyant RJ, Gubish CT, Landreneau RJ. The clinical significance of hepatocyte growth factor for non-small cell lung cancer. Ann Thorac Surg 1998; 66: 1915-1918.

26. Nakamura T, Matumoto K, Kiritoshi A, Tano Y, Nakamura T. Induction of hepatocyte grwth factor in fibroblasts by tumor-derived factors affect invasive growth of tumor cells: in vitro analysis of tumor-stromal interactions. Cancer Res 1997; 57: 3305-3313.

27. Berger W, Setinek U, Mohr T, Kindas-Mugge I, Vetterlein M, Dekan G, Eckersberger F, Caldas C, Micksche M. Evidence for a role of FGF-2 and FGF receptors in the proliferation of non-small cell lung cancer cells. Int J Cancer 1999; 83: 415-423.
28. Guddo F, Fontanini G, Reina C, Vignola AM, Angeletti A, Bonsignore G. The expression of basic fibroblast growth factor (bFGF) in tumorassociated stromal cells and vessels in inversely correlated with nonsmall cell lung cancer progression. Hum Patbol 1999; 30: 788-794.

29. Watanabe K, Takahashi H, Habu Y, Kamiya-Kubushiro N, Kamiya S, Nakamura H, Yajima $H$, Ishii $T$, Katayama $T$, Miyazaki K, Fukai $F$. Interaction with heparin and matrix metalloproteinase 2 cleavage expose a criptc ant-adhensive site of fibronectin. Biochemistry 2000;39: 7138-7144.

30. Kramer R, Vogel KG, Nicolson GL. Solublization and degradation of subendothlial matrix glycoproteins and proteoglycans by metastatic tumor cells. J Biol Chem 1982; 256: 2678-2686.

31. Irimura T, Nakajima M, Nicolson GI. Chemical modified heparin as inhibitors of heparan sulfate specific endo- $\beta$-glucuronidase (Heparanase) of metastatic melanoma cells. Biochemistry 1986; 25: 5322-5328.

32. Miao H, Elkin M, Aingorn E, Ishai-Michaeli R, Stein CA, Vlodavsky I. Inhibition of heparanase activity and tumor metastasis by laminarin sulfate and synthetic phodphorothioate oligodeoxynucleotides. Int J Cancer 1999; 83: 424-431.

33. Parish CR, Freeman C, Brown KJ, Francis DJ, Cowden WB. Identification of sulfated oligosaccharide-based inhibitors of tumor growth and metastasis using novel in vitro assays for angiogenesis and heparanase activity. Cancer Res 1999; 59: 3433-3441.

34. Hamada K, Kita E, Sawaki M, Mikasa K, Narita N. Antitumor effect of erythromycin. Chemotherapy 1995; 41: 59-69.

35. Hamada K, Mikasa K, Yunou Y, Kurioka T, Majima T, Narita N, Kita E. Adjuvant effect of clarithromycin on chemotherapy for murine lung cancer. Chemotherapy 2000; 46: 49-61.

\section{Received 26 July 2001; \\ Accepted 9 August 2001}




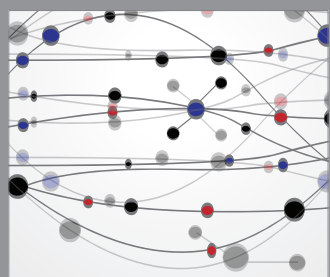

The Scientific World Journal
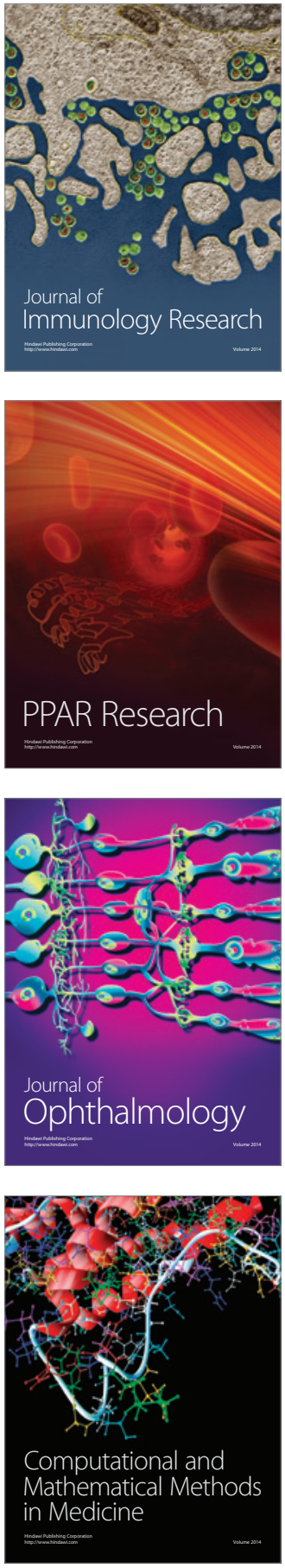

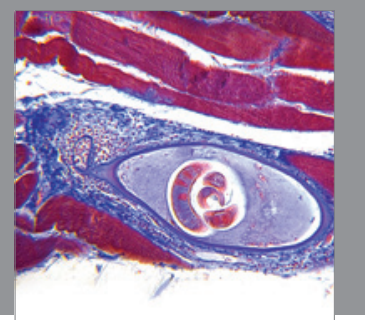

Gastroenterology

Research and Practice
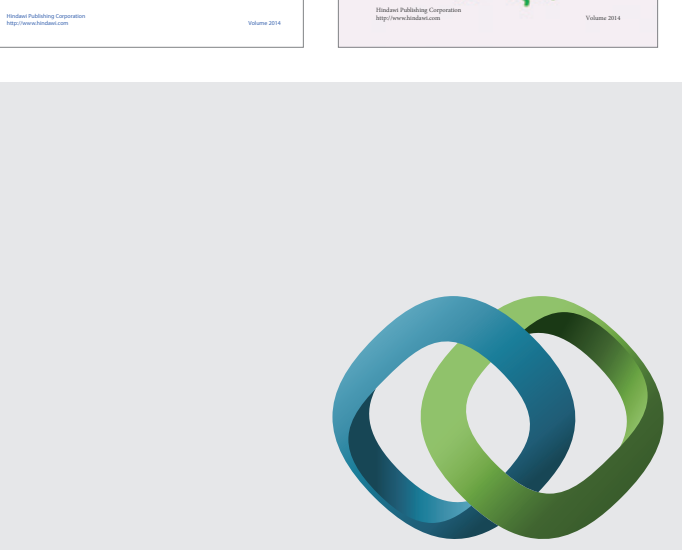

\section{Hindawi}

Submit your manuscripts at

http://www.hindawi.com
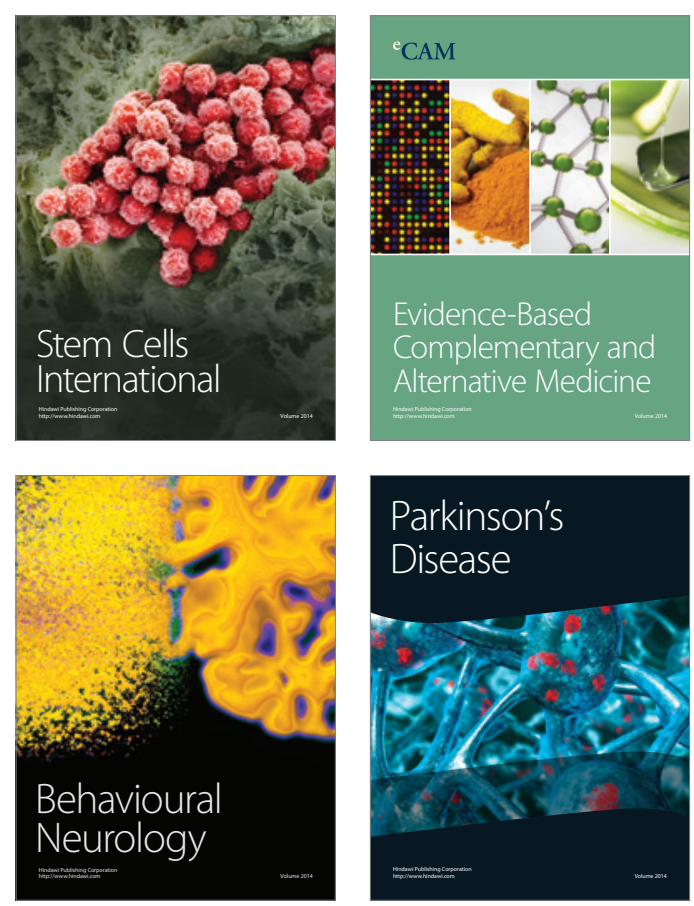

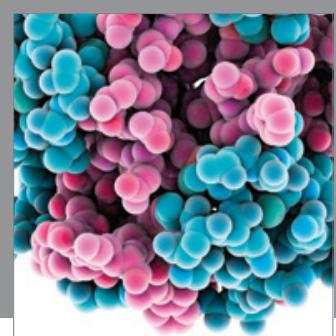

Journal of
Diabetes Research

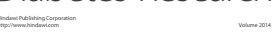

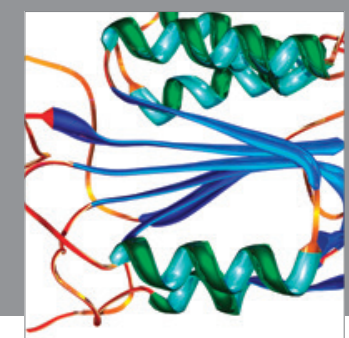

Disease Markers
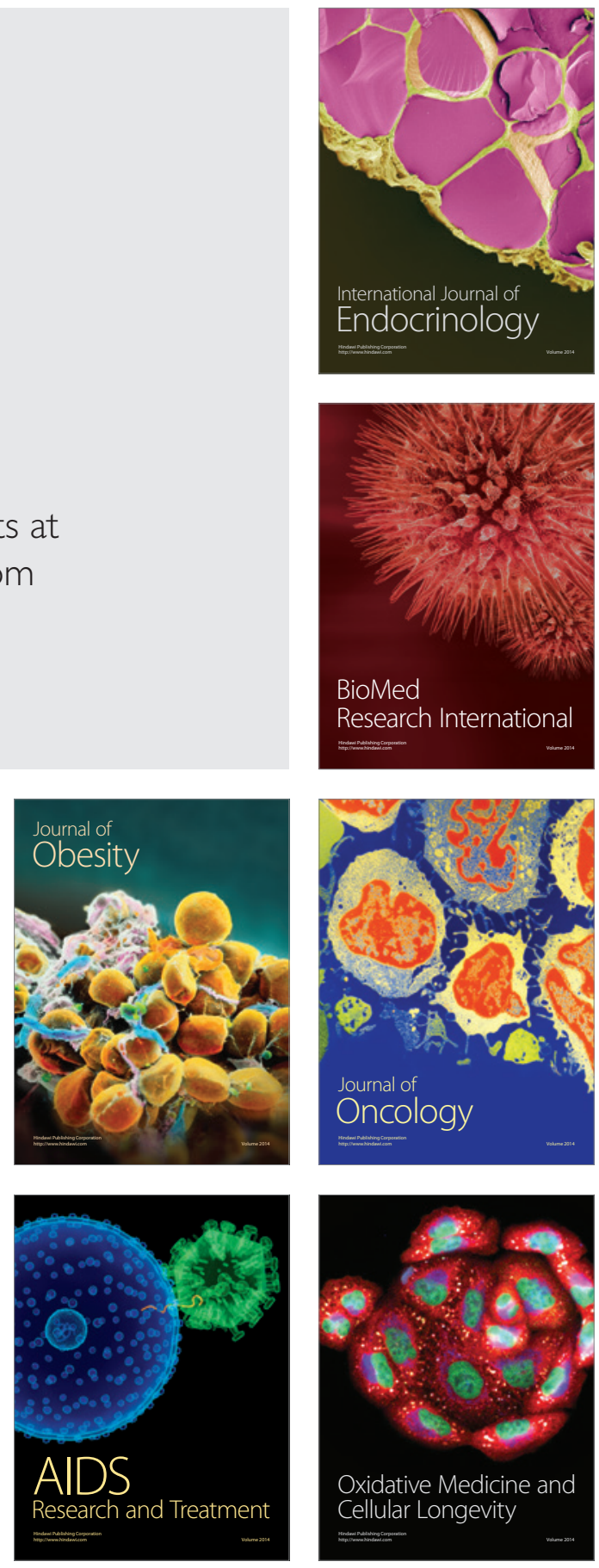